\title{
Reinvestigations of the $\mathrm{Li}_{2} \mathrm{O}-\mathrm{WO}_{3}$ system
}

\author{
Piotr Tabero $^{1}$ (D) Artur Frackowiak $^{1}$
}

Received: 1 December 2016/Accepted: 24 March 2017/Published online: 6 April 2017

(c) The Author(s) 2017. This article is an open access publication

\begin{abstract}
Reinvestigations of the $\mathrm{Li}_{2} \mathrm{O}-\mathrm{WO}_{3}$ system have been performed with the help of DTA-TG, XRD, IR and UV-Vis-NIR/DRS measuring techniques and $\mathrm{WO}_{3}$ and $\mathrm{Li}_{2} \mathrm{CO}_{3}$ as a reactants. Results of investigations have shown that using applied procedure of synthesis four single phases have been obtained: $\mathrm{Li}_{2} \mathrm{WO}_{4}, \mathrm{Li}_{2} \mathrm{~W}_{2} \mathrm{O}_{7}, \alpha-\mathrm{Li}_{4} \mathrm{WO}_{5}$ and $\beta$ $\mathrm{Li}_{4} \mathrm{WO}_{5}$. We failed to obtain pure samples of $\mathrm{Li}_{2} \mathrm{~W}_{5} \mathrm{O}_{16}$, $\mathrm{Li}_{2} \mathrm{~W}_{4} \mathrm{O}_{13}$ and $\mathrm{Li}_{6} \mathrm{~W}_{2} \mathrm{O}_{9}$, although diffraction reflection characteristic for these phases was identified on powder diffraction patterns of several samples. On the other hand, the formation of $\mathrm{Li}_{6} \mathrm{WO}_{6}$ has not been corroborated by XRD in our research. Results of DTA-TG investigations have revealed that phases $\mathrm{Li}_{2} \mathrm{~W}_{2} \mathrm{O}_{7}$ and $\mathrm{Li}_{2} \mathrm{WO}_{4}$ melt congruently at 735 and $745{ }^{\circ} \mathrm{C}$, respectively, whereas $\alpha$ $\mathrm{Li}_{4} \mathrm{WO}_{5}$ undergoes a phase transition to $\beta-\mathrm{Li}_{4} \mathrm{WO}_{5}$ at $690{ }^{\circ} \mathrm{C}$. Results of DTA-TG and IR investigations indicate that $\alpha-\mathrm{Li}_{4} \mathrm{WO}_{5}$ can be stabilized by a small amount of carbonate groups. Based on UV-Vis-NIR/DRS investigations, band gap energies were calculated for $\mathrm{Li}_{2} \mathrm{WO}_{4}$, $\mathrm{Li}_{2} \mathrm{~W}_{2} \mathrm{O}_{7}, \alpha-\mathrm{Li}_{4} \mathrm{WO}_{5}$ and $\beta-\mathrm{Li}_{4} \mathrm{WO}_{5}$ and are equal to 4.35 , $4.03,4.00$ and $4.12 \mathrm{eV}$, respectively.
\end{abstract}

Keywords $\mathrm{Li}_{2} \mathrm{O}-\mathrm{WO}_{3}$ system $\cdot \mathrm{DTA}-\mathrm{TG} \cdot \mathrm{XRD} \cdot \mathrm{IR}$. UV-Vis-NIR/DRS · Band gap

Piotr Tabero

ptab@zut.edu.pl

1 Szczecin, Faculty of Chemical Technology and Engineering, Department of Inorganic and Analytical Chemistry, West Pomeranian University of Technology, Al. Piastow 42 , 71-065 Szczecin, Poland

\section{Introduction}

Literature scan has shown that $\mathrm{Li}_{2} \mathrm{O}-\mathrm{WO}_{3}$ system has been the subject of many studies [1-22]. Phases forming in this system owing to their interesting properties are potential candidates for the production of components of electrodes for lithium batteries, catalysts of oxidative coupling of light hydrocarbons, fluxes for single crystal growing, electrochromic and photochromic devices as well as neutron detectors [1-4]. Previous studies on the $\mathrm{Li}_{2} \mathrm{O}-\mathrm{WO}_{3}$ system have revealed the formation of seven binary compounds: $\mathrm{Li}_{6} \mathrm{WO}_{6}, \mathrm{Li}_{4} \mathrm{WO}_{5}, \mathrm{Li}_{6} \mathrm{~W}_{2} \mathrm{O}_{9}, \mathrm{Li}_{2} \mathrm{WO}_{4}, \mathrm{Li}_{2} \mathrm{~W}_{2} \mathrm{O}_{7}, \mathrm{Li}_{2} \mathrm{~W}_{4} \mathrm{O}_{13}$ and $\mathrm{Li}_{2} \mathrm{~W}_{5} \mathrm{O}_{16}$. Synthesis of phases has been conducted in air, oxygen or dry oxygen using $\mathrm{Li}_{2} \mathrm{O} / \mathrm{WO}_{3}, \mathrm{Li}_{2} \mathrm{O}_{2} / \mathrm{WO}_{3}$, $\mathrm{LiOH} / \mathrm{WO}_{3}, \mathrm{Li}_{2} \mathrm{CO}_{3} / \mathrm{H}_{2} \mathrm{WO}_{4}$ and the most frequently $\mathrm{Li}_{2}$ $\mathrm{CO}_{3} / \mathrm{WO}_{3}$ mixtures. Conducted investigations enabled construction of two variants of phase diagram of the $\mathrm{Li}_{2}$ $\mathrm{WO}_{4}-\mathrm{WO}_{3}$ system $[5,6]$ and one of the $\mathrm{WO}_{3}-\mathrm{Li}_{2} \mathrm{O}$ system [7]. IR spectra of $\mathrm{Li}_{2} \mathrm{~W}_{2} \mathrm{O}_{7}, \mathrm{Li}_{2} \mathrm{WO}_{4}, \mathrm{Li}_{2} \mathrm{~W}_{4} \mathrm{O}_{13} \mathrm{Li}_{6} \mathrm{WO}_{6}$ as well as $\alpha$ and $\beta$ modifications of $\mathrm{Li}_{4} \mathrm{WO}_{5}$ are known [7, 8].

Basic crystallographic data of phases forming in the system $\mathrm{Li}_{2} \mathrm{O}-\mathrm{WO}_{3}$ are given in Table 1 .

Literature survey has shown that $\mathrm{Li}_{2} \mathrm{WO}_{4}$ forms four polymorphs: rhombohedral $\mathrm{Li}_{2} \mathrm{WO}_{4}$-I, of phenacite structure and stable at atmospheric pressure, tetragonal $\mathrm{Li}_{2}$ $\mathrm{WO}_{4}$-II obtained at $300 \mathrm{MPa}$, an orthorhombic $\mathrm{Li}_{2} \mathrm{WO}_{4^{-}}$ III, prepared above $300 \mathrm{MPa}$ and at higher temperature than $\mathrm{Li}_{2} \mathrm{WO}_{4}$-II and monoclinic $\mathrm{Li}_{2} \mathrm{WO}_{4}$-IV stable at pressure higher than $\mathrm{Li}_{2} \mathrm{WO}_{4}$-III [9-12]. Crystal structures of rhombohedral, tetragonal and monoclinic structures of $\mathrm{Li}_{2} \mathrm{WO}_{4}$ were solved $[9,10,13] . \mathrm{Li}_{2} \mathrm{WO}_{4}$ melts at $738^{\circ} \mathrm{C}$ [14] $740{ }^{\circ} \mathrm{C}[7,11]$ or $742{ }^{\circ} \mathrm{C}$ [6]. If it is heated to well above its melting point at atmospheric pressure, some loss of $\mathrm{Li}_{2} \mathrm{O}$ occurs by evaporation, yielding a mixture of $\mathrm{Li}_{2}$ $\mathrm{W}_{2} \mathrm{O}_{7}$ and $\mathrm{Li}_{2} \mathrm{WO}_{4}$ [11]. 
Table 1 Basic crystallographic data of phases forming in the $\mathrm{Li}_{2} \mathrm{O}-\mathrm{WO}_{3}$ system, where CS—crystal system, 3-triclinic, $\mathrm{M}-$ monoclinic, $\mathrm{O}-$ orthorhombic, $\mathrm{R}$-rhombohedral, $\mathrm{T}$ - tetragonal, $\mathrm{H}$-hexagonal, $\mathrm{C}$-cubic

\begin{tabular}{|c|c|c|c|c|c|c|c|c|c|c|}
\hline \multirow[t]{2}{*}{ Formula } & \multirow[t]{2}{*}{$\mathrm{Li}_{2} \mathrm{O} / \% \mathrm{~mol}$} & \multirow[t]{2}{*}{$\mathrm{CS}$} & \multirow[t]{2}{*}{ Space group } & \multicolumn{6}{|c|}{ Unit cell parameters } & \multirow[t]{2}{*}{ References } \\
\hline & & & & $\mathrm{a} / \mathrm{nm}$ & $\mathrm{b} / \mathrm{nm}$ & $\mathrm{c} / \mathrm{nm}$ & $\alpha /^{\circ}$ & $\beta /^{\circ}$ & $\gamma /{ }^{\circ}$ & \\
\hline $\mathrm{Li}_{2} \mathrm{~W}_{5} \mathrm{O}_{16}$ & 16.67 & - & - & - & - & - & - & - & - & {$[5]$} \\
\hline $\mathrm{Li}_{2} \mathrm{~W}_{4} \mathrm{O}_{13}$ & 20.00 & - & - & - & - & - & - & - & - & {$[18]$} \\
\hline $\mathrm{Li}_{2} \mathrm{~W}_{2} \mathrm{O}_{7}$ & 33.33 & 3 & $\mathrm{P}-1$ & 0.8280 & 0.7050 & 0.5040 & 85.40 & 102.13 & 110.29 & [19] \\
\hline \multirow[t]{6}{*}{$\mathrm{Li}_{2} \mathrm{WO}_{4}$} & 50.00 & $\mathrm{O}$ & - & 1.0124 & 1.1686 & 1.0071 & 90.00 & 90.00 & 90.00 & [12] \\
\hline & & $\mathrm{O}$ & - & 0.5063 & 1.0076 & 1.1610 & 90.00 & 90.00 & 90.00 & [21] \\
\hline & & $\mathrm{O}$ & - & 0.5940 & 0.9730 & 0.4970 & 90.00 & 90.00 & 90.00 & [12] \\
\hline & & $\mathrm{T}$ & 141/amd & 1.1941 & 1.1941 & 0.8409 & 90.00 & 90.00 & 90.00 & [11] \\
\hline & & M & $\mathrm{C} 2 / \mathrm{c}$ & 0.9755 & 0.5946 & 0.4993 & 90.00 & 90.56 & 90.00 & [10] \\
\hline & & $\mathrm{R}$ & $\mathrm{R}-3$ & 1.4361 & 1.4361 & 0.9603 & 90.00 & 90.00 & 120.00 & [13] \\
\hline $\mathrm{Li}_{6} \mathrm{~W}_{2} \mathrm{O}_{9}$ & 60.00 & $\mathrm{C}$ & Pm-3 m & 0.8310 & 0.8310 & 0.8310 & 90.00 & 90.00 & 90.00 & [17] \\
\hline \multirow[t]{4}{*}{$\mathrm{Li}_{4} \mathrm{WO}_{5}$} & 66.67 & $\mathrm{C}$ & - & 0.8290 & 0.8290 & 0.8290 & 90.00 & 90.00 & 90.00 & [15] \\
\hline & & $\mathrm{C}$ & - & 0.4150 & 0.4150 & 0.4150 & 90.00 & 90.00 & 90.00 & [20] \\
\hline & & $\mathrm{O}$ & - & 2.4700 & 0.8780 & 2.8900 & 90.00 & 90.00 & 90.00 & [15] \\
\hline & & 3 & P-1 & 0.5109 & 0.7716 & 0.5061 & 101.80 & 101.78 & 108.77 & [22] \\
\hline \multirow[t]{2}{*}{$\mathrm{Li}_{6} \mathrm{WO}_{6}$} & 75.00 & $\mathrm{O}$ & - & 0.7410 & 0.7790 & 0.8880 & 90.00 & 90.00 & 90.00 & [15] \\
\hline & & $\mathrm{O}$ & Immm & 0.8902 & 0.2879 & 0.4090 & 90.00 & 90.00 & 90.00 & [16] \\
\hline
\end{tabular}

$\mathrm{Li}_{6} \mathrm{WO}_{6}$ has been obtained as a result of the reaction of $\mathrm{Li}_{4} \mathrm{WO}_{5}$ with $\mathrm{Li}_{2} \mathrm{O}$ at $500{ }^{\circ} \mathrm{C}$ or $\mathrm{LiOH}$ with $\mathrm{WO}_{3}$ at $700{ }^{\circ} \mathrm{C}$ in dry oxygen [15, 16]; however, Lv and co-workers [4] failed to obtain this phase. At high temperature, $\mathrm{Li}_{6} \mathrm{WO}_{6}$ has homogeneity range, and below $440{ }^{\circ} \mathrm{C}$, it decomposes into $\mathrm{Li}_{2} \mathrm{O}$ and $\mathrm{Li}_{4} \mathrm{WO}_{5}$ [7]. Reau and co-workers have shown in contrast that it decomposes at $1000{ }^{\circ} \mathrm{C}$ yielding $\beta-\mathrm{Li}_{4} \mathrm{WO}_{5}$ and volatile $\mathrm{Li}_{2} \mathrm{O}$ [15]. Crystal structure of orthorhombic $\mathrm{Li}_{6} \mathrm{WO}_{6}$ has been solved by Hauck [16].

Another phase forming in the system $\mathrm{Li}_{2} \mathrm{O}-\mathrm{WO}_{3}, \mathrm{Li}_{2}$ $\mathrm{W}_{5} \mathrm{O}_{16}$, melts incongruently at $820^{\circ} \mathrm{C}[4,5,17]$, whereas $\mathrm{Li}_{2} \mathrm{~W}_{4} \mathrm{O}_{13}$ melts incongruently at $805^{\circ} \mathrm{C}[6], 800{ }^{\circ} \mathrm{C}$ $[7,13]$ or at $750{ }^{\circ} \mathrm{C}[18]$ with the deposition of $\mathrm{Li}_{2} \mathrm{~W}_{2} \mathrm{O}_{7}$ and $\mathrm{WO}_{3}[18]$.

Pistorius [11] has found that $\mathrm{Li}_{2} \mathrm{~W}_{2} \mathrm{O}_{7}$ undergoes to sharp and reversible phase transition at $666{ }^{\circ} \mathrm{C}$ with a large latent heat. This phase melts congruently at $660^{\circ} \mathrm{C}$ [18], $745{ }^{\circ} \mathrm{C}[5-7]$ or $754{ }^{\circ} \mathrm{C}$ [13]. Crystal structure of $\mathrm{Li}_{2} \mathrm{~W}_{2} \mathrm{O}_{7}$ was solved by Okada and co-workers [19].

Permentier and co-workers [17] conducing synthesis in the temperature range of $450-500{ }^{\circ} \mathrm{C}$ have obtained $\mathrm{Li}_{6}$ $\mathrm{W}_{2} \mathrm{O}_{9}$. According to Authors, $\mathrm{Li}_{6} \mathrm{~W}_{2} \mathrm{O}_{9}$ decomposes at $550{ }^{\circ} \mathrm{C}$ with the formation of $\mathrm{Li}_{2} \mathrm{WO}_{4}$ and $\beta-\mathrm{Li}_{4} \mathrm{WO}_{5}$.

Literature survey has shown that $\mathrm{Li}_{4} \mathrm{WO}_{5}$ forms two polymorphic modifications: low-temperature modification, crystallizing in cubic system $\alpha-\mathrm{Li}_{4} \mathrm{WO}_{5}$ and high-temperature modification, crystallizing in triclinic or orthorhombic system $\beta-\mathrm{Li}_{4} \mathrm{WO}_{5}[7,15,20,22]$. At $690{ }^{\circ} \mathrm{C}, \alpha-\mathrm{Li}_{4} \mathrm{WO}_{5}$ undergoes to phase transition to $\beta-\mathrm{Li}_{4} \mathrm{WO}_{5}[7,15]$. According to Hauck [7], $\beta-\mathrm{Li}_{4} \mathrm{WO}_{5}$ melts at $1350{ }^{\circ} \mathrm{C}$, but Rau and co-workers [15] have shown that it decomposes at $1100{ }^{\circ} \mathrm{C}$ yielding $\mathrm{Li}_{2} \mathrm{WO}_{4}$ and volatile in these conditions $\mathrm{Li}_{2} \mathrm{O} . \alpha-\mathrm{Li}_{4} \mathrm{WO}_{5}$ can be obtained in different degrees of order-disorder depending on temperature and time of synthesis [7]. Ordered form obtained at higher temperature cannot be transferred to disordered form by heating at lower temperatures. Blasse suggests that cubic modification has disordered rock salt structure [20].

Above-presented literature survey has shown that despite numerous works published, until now there are still controversies concerning the number and composition of forming phases and conditions of their synthesis. The aim of this work was to verify literature data on $\mathrm{Li}_{2} \mathrm{O}-\mathrm{WO}_{3}$ system.

\section{Experimental}

The following materials were used for the research: $\mathrm{WO}_{3}$, 99.9\% (Fluka AG, USA), and $\mathrm{Li}_{2} \mathrm{CO}_{3}$, a.p. (POCh, Poland).

For the experiments, seven samples were selected with contents corresponding to $\mathrm{Li}_{2} \mathrm{~W}_{5} \mathrm{O}_{16}, \mathrm{Li}_{2} \mathrm{~W}_{4} \mathrm{O}_{13}, \mathrm{Li}_{2} \mathrm{~W}_{2} \mathrm{O}_{7}$, $\mathrm{Li}_{2} \mathrm{WO}_{4}, \mathrm{Li}_{6} \mathrm{~W}_{2} \mathrm{O}_{9}, \mathrm{Li}_{4} \mathrm{WO}_{5}$ and $\mathrm{Li}_{6} \mathrm{WO}_{6}$. They represented all described in literature phases forming in the system $\mathrm{Li}_{2} \mathrm{O}-\mathrm{WO}_{3}$. Mixtures of $\mathrm{Li}_{2} \mathrm{CO}_{3}$ and $\mathrm{WO}_{3}$ weighed 
in suitable proportions enabling preparation of $5 \mathrm{~g}$ of final product were homogenized in an agate mortar and calcinated at $450,500,550,600,650$ and $700{ }^{\circ} \mathrm{C}$ in 24 -h stages in an air atmosphere. After each heating stage, the samples were cooled down to room temperature with furnace, powdered in mortar and examined with the help of XRD. The pure phases obtained in this work were examined additionally by the DTA-TG, UV-Vis-IR/DRS and IR methods. These measuring methods were selected because they allow determination of phase composition of samples, establishing their melting temperatures as well as melting behaviour [23-30].

$\mathrm{X}$-ray phase analysis (XRD) of the samples was performed using an Empyrean II diffractometer (PANalytical, The Nederlands, copper radiation filtered with a graphite monochromator) with the help of Highscore + software (PANalyticak, The Nederlands) and PDF4 + ICDD database.

The DTA-TG examinations were made with the aid of an apparatus of Paulik-Paulik-Erdey type (MOM, Hungary). Samples of $500 \mathrm{mg}$ were investigated in air up to the $1000{ }^{\circ} \mathrm{C}$ at the heating rate of $10^{\circ} \mathrm{C} \mathrm{min}^{-1}$ using quartz crucibles.

The IR spectra were registered by Specord M80 spectrometer (Carl Zeiss, Jena, Germany) in the wavenumber region of $1500-200 \mathrm{~cm}^{-1}$ using halide discs technique (pellets in $\mathrm{KBr}$ at a mass ratio 1:300).

The NIR/DRS measurements were performed using a Jasco V670 spectrometer matched with integrating sphere PIN 757 (Jasco, Japan) with Spectralon as a reference material.

\section{Results and discussion}

Samples obtained after consecutive stage of heating have been subjected to XRD investigations. Results of X-ray phase analysis are given in Table 2. Analysis of data presented in Table 2 shows that in all cases synthesis starts at $450{ }^{\circ} \mathrm{C}$, but is very slow at this temperature. Moreover, syntheses processes are complex and run with formation of several intermediates. Only in the case of $\mathrm{Li}_{2} \mathrm{~W}_{2} \mathrm{O}_{7}, \mathrm{Li}_{2}$ $\mathrm{WO}_{4}, \alpha-\mathrm{Li}_{4} \mathrm{WO}_{5}$ and $\beta-\mathrm{Li}_{4} \mathrm{WO}_{5}$ obtained samples were single phase. In accord with literature data $[7,15]$ in the temperature range of $650-700{ }^{\circ} \mathrm{C}, \alpha-\mathrm{Li}_{4} \mathrm{WO}_{5}$ undergoes to phase transition to high-temperature modification, $\beta-\mathrm{Li}_{4}$ $\mathrm{WO}_{5}$. We failed to obtain pure samples of $\mathrm{Li}_{2} \mathrm{~W}_{5} \mathrm{O}_{16}$, $\mathrm{Li}_{2} \mathrm{~W}_{4} \mathrm{O}_{13}$ and $\mathrm{Li}_{6} \mathrm{~W}_{2} \mathrm{O}_{9}$, although diffraction reflection characteristic for these phases was identified on powder diffraction patterns of several samples. It was very characteristic for $\mathrm{Li}_{6} \mathrm{~W}_{2} \mathrm{O}_{9}$, whose diffraction reflections have been detected on diffraction patterns of all samples. On the other hand, the formation of $\mathrm{Li}_{6} \mathrm{WO}_{6}$ has not been
Table 2 Results of X-ray phase analysis after consecutive stages of heating, where $\mathrm{Li}-\mathrm{Li}_{2} \mathrm{CO}_{3}, \mathrm{~W}-\mathrm{WO}_{3}, \mathrm{O} 4-\mathrm{Li}_{2} \mathrm{WO}_{4}, \alpha-\alpha-\mathrm{Li}_{4} \mathrm{WO}_{5}$, $\beta-\beta-\mathrm{Li}_{4} \mathrm{WO}_{5}, \mathrm{O} 6-\mathrm{Li}_{6} \mathrm{WO}_{6}, \mathrm{O} 7-\mathrm{Li}_{2} \mathrm{~W}_{2} \mathrm{O}_{7}, \mathrm{O} 9-\mathrm{Li}_{6} \mathrm{~W}_{2} \mathrm{O}_{9}, \mathrm{O} 13-$ $\mathrm{Li}_{2} \mathrm{~W}_{4} \mathrm{O}_{13}, \mathrm{O} 16-\mathrm{Li}_{2} \mathrm{~W}_{5} \mathrm{O}_{16}, \mathrm{X}$ - unknown phase

\begin{tabular}{|c|c|c|c|c|c|c|c|}
\hline \multirow[t]{2}{*}{ Phase } & \multirow[t]{2}{*}{$\mathrm{Li}_{2} \mathrm{O} / \% \mathrm{~mol}$} & \multicolumn{6}{|c|}{$\begin{array}{l}\text { Products detected after heating stage at } \\
\text { temperature } /{ }^{\circ} \mathrm{C}\end{array}$} \\
\hline & & 450 & 500 & 550 & 600 & 650 & 700 \\
\hline \multirow[t]{5}{*}{$\mathrm{Li}_{2} \mathrm{~W}_{5} \mathrm{O}_{16}$} & 16.67 & $\mathrm{O} 4$ & $\mathrm{O} 4$ & O4 & $\mathrm{O} 7$ & $\mathrm{O} 7$ & $\mathrm{O} 13$ \\
\hline & & $\mathrm{O} 7$ & $\mathrm{O} 7$ & $\mathrm{O} 7$ & $\mathrm{O} 13$ & O13 & O16 \\
\hline & & O9 & O9 & $\mathrm{O} 13$ & $\mathrm{Li}$ & $\mathrm{Li}$ & $X$ \\
\hline & & $\mathrm{Li}$ & $\mathrm{Li}$ & $\mathrm{Li}$ & W & W & \\
\hline & & W & W & W & & & \\
\hline \multirow[t]{5}{*}{$\mathrm{Li}_{2} \mathrm{~W}_{4} \mathrm{O}_{13}$} & 20.00 & $\mathrm{O} 4$ & $\mathrm{O} 4$ & $\mathrm{O} 4$ & $\mathrm{O} 7$ & $\mathrm{O} 7$ & $\mathrm{O} 7$ \\
\hline & & $\mathrm{O} 7$ & $\mathrm{O} 7$ & O7 & $\mathrm{O} 13$ & O13 & $\mathrm{O} 13$ \\
\hline & & O9 & O9 & O13 & $\mathrm{Li}$ & $\mathrm{Li}$ & O16 \\
\hline & & $\mathrm{Li}$ & $\mathrm{Li}$ & $\mathrm{Li}$ & W & W & $X$ \\
\hline & & W & W & W & & & \\
\hline \multirow[t]{5}{*}{$\mathrm{Li}_{2} \mathrm{~W}_{2} \mathrm{O}_{7}$} & 33.33 & O4 & $\mathrm{O} 4$ & $\mathrm{O} 4$ & O4 & $\mathrm{O} 7$ & $\mathrm{O} 7$ \\
\hline & & O7 & $\mathrm{O} 7$ & O7 & O7 & & \\
\hline & & O9 & O9 & O9 & & & \\
\hline & & $\mathrm{Li}$ & $\mathrm{Li}$ & W & & & \\
\hline & & W & W & & & & \\
\hline \multirow[t]{5}{*}{$\mathrm{Li}_{2} \mathrm{WO}_{4}$} & 50.00 & O4 & $\mathrm{O} 4$ & $\mathrm{O} 4$ & $\mathrm{O} 4$ & $\mathrm{O} 4$ & O4 \\
\hline & & $\mathrm{O} 7$ & $\mathrm{O} 7$ & O7 & $\mathrm{O} 7$ & & \\
\hline & & O9 & O9 & O9 & & & \\
\hline & & $\mathrm{Li}$ & $\mathrm{Li}$ & & & & \\
\hline & & W & W & & & & \\
\hline \multirow[t]{5}{*}{$\mathrm{Li}_{6} \mathrm{~W}_{2} \mathrm{O}_{9}$} & 60.00 & $\mathrm{O} 4$ & $\mathrm{O} 4$ & O4 & $\mathrm{O} 4$ & O4 & $\mathrm{O} 4$ \\
\hline & & $\mathrm{O} 7$ & $\mathrm{O} 7$ & $\alpha$ & $\alpha$ & $\alpha$ & $\beta$ \\
\hline & & O9 & O9 & $\mathrm{Li}$ & $\mathrm{Li}$ & & \\
\hline & & $\mathrm{Li}$ & $\mathrm{Li}$ & O9 & & & \\
\hline & & W & W & & & & \\
\hline \multirow[t]{5}{*}{$\mathrm{Li}_{4} \mathrm{WO}_{5}$} & 66.67 & O4 & O4 & O4 & O4 & $\alpha$ & $\beta$ \\
\hline & & O7 & $\mathrm{O} 7$ & O7 & O7 & & \\
\hline & & O9 & O9 & O9 & O9 & & \\
\hline & & $\mathrm{Li}$ & $\mathrm{Li}$ & $\mathrm{Li}$ & $\mathrm{Li}$ & & \\
\hline & & W & $\alpha$ & $\alpha$ & $\alpha$ & & \\
\hline \multirow[t]{5}{*}{$\mathrm{Li}_{6} \mathrm{WO}_{6}$} & 75.00 & O4 & $\mathrm{O} 4$ & O9 & O9 & $\mathrm{Li}$ & $\mathrm{Li}$ \\
\hline & & O7 & O7 & $\mathrm{Li}$ & $\mathrm{Li}$ & $\alpha$ & $\beta$ \\
\hline & & O9 & O9 & $\alpha$ & $\alpha$ & & \\
\hline & & $\mathrm{Li}$ & $\mathrm{Li}$ & & & & \\
\hline & & W & & & & & \\
\hline
\end{tabular}

corroborated by XRD in our research. We have encountered some problems with X-ray phase analysis of investigated samples. The lack of structural data in the cases of $\mathrm{Li}_{2} \mathrm{~W}_{5} \mathrm{O}_{16}, \mathrm{Li}_{2} \mathrm{~W}_{4} \mathrm{O}_{13}, \alpha-\mathrm{Li}_{4} \mathrm{WO}_{5}$ and poor-quality X-ray data in some other cases makes $\mathrm{X}$-ray phase analysis in the $\mathrm{Li}_{2} \mathrm{O}-\mathrm{WO}_{3}$ system very difficult.

Powder diffraction patterns of single-phase samples of $\mathrm{Li}_{2} \mathrm{~W}_{2} \mathrm{O}_{7}, \quad \mathrm{Li}_{2} \mathrm{WO}_{4}, \quad \alpha-\mathrm{Li}_{4} \mathrm{WO}_{5}$ and $\beta-\mathrm{Li}_{4} \mathrm{WO}_{5}$ were 
Table 3 Unit cell parameters and volumes of $\mathrm{Li}_{2} \mathrm{WO}_{4}, \mathrm{Li}_{2} \mathrm{~W}_{2} \mathrm{O}_{7}, \alpha-\mathrm{Li}_{4} \mathrm{WO}_{5}, \beta-\mathrm{Li}_{4} \mathrm{WO}_{5}$ phases obtained in this work

\begin{tabular}{llllllllr}
\hline No. & Formula & $\mathrm{a} / \mathrm{nm}$ & $\mathrm{b} / \mathrm{nm}$ & $\mathrm{c} / \mathrm{nm}$ & $\alpha /^{\circ}$ & $\beta /{ }^{\circ}$ & $\gamma /{ }^{\circ}$ & $\mathrm{V} / \mathrm{nm}^{3}$ \\
\hline 1 & $\mathrm{Li}_{2} \mathrm{WO}_{4}$ & $1.4376(1)$ & $1.4376(1)$ & $0.9616(1)$ & 90.00 & 90.00 & 120.00 & 1.7211 \\
2 & $\mathrm{Li}_{2} \mathrm{~W}_{2} \mathrm{O}_{7}$ & $0.8293(4)$ & $0.7058(3)$ & $0.5057(6)$ & $85.20(5)$ & $102.28(7)$ & $110.37(6)$ & 0.2711 \\
3 & $\alpha-\mathrm{Li}_{4} \mathrm{WO}_{5}$ & $0.4167(1)$ & $0.4167(1)$ & $0.4167(1)$ & 90.00 & 90.00 & 90.00 & 0.0724 \\
4 & $\beta-\mathrm{Li}_{4} \mathrm{WO}_{5}$ & $0.5136(1)$ & $0.7755(1)$ & $0.5086(1)$ & $101.60(2)$ & $101.53(2)$ & $108.50(2)$ & 0.1804 \\
\hline
\end{tabular}

Table 4 Result of indexing of X-ray powder diffraction pattern of the triclinic $\beta-\mathrm{Li}_{4} \mathrm{WO}_{5}$ obtained in this work

\begin{tabular}{|c|c|c|c|c|c|c|c|c|c|}
\hline Lp. & $d_{\mathrm{exp}} / \mathrm{nm}$ & $d_{\text {calc }} / \mathrm{nm}$ & (hkl) & $100 \mathrm{I}$ & Lp. & $d_{\mathrm{exp}} / \mathrm{nm}$ & $d_{\text {calc }} / \mathrm{nm}$ & (hkl) & $100 \mathrm{I}$ \\
\hline 1 & 2 & 3 & 4 & 5 & 1 & 2 & 3 & 4 & 5 \\
\hline 1 & 0.70474 & 0.70503 & 010 & 3 & 18 & 0.23909 & 0.23887 & 002 & 10 \\
\hline 2 & 0.48036 & 0.48035 & -110 & 100 & 19 & 0.23733 & 0.23731 & $1-31$ & 2 \\
\hline 3 & 0.46708 & 0.46701 & 100 & 5 & 20 & 0.23500 & 0.23501 & 030 & 3 \\
\hline 4 & 0.46130 & 0.46115 & $0-11$ & 30 & 21 & 0.23348 & 0.23351 & 200 & 6 \\
\hline 5 & 0.39463 & 0.39464 & -101 & 16 & 22 & 0.23043 & 0.23057 & $0-22$ & 3 \\
\hline 6 & 0.35659 & 0.35668 & -111 & 11 & 23 & 0.22352 & 0.22356 & -221 & 5 \\
\hline 7 & 0.35243 & 0.35252 & 020 & 31 & 24 & 0.21095 & 0.21092 & $-2-11$ & 16 \\
\hline 8 & 0.33597 & 0.33596 & 110 & 18 & 25 & 0.20937 & 0.20929 & $-1-22$ & 24 \\
\hline 9 & 0.33252 & 0.33247 & $0-21$ & 7 & 26 & 0.20659 & 0.20661 & $2-21$ & 3 \\
\hline 10 & 0.32318 & 0.32325 & $1-11$ & 12 & 27 & 0.20429 & 0.2043 & $1-22$ & 20 \\
\hline 11 & 0.29459 & 0.29473 & 101 & 5 & 28 & 0.20047 & 0.20049 & 210 & 1 \\
\hline 12 & 0.29299 & 0.29296 & $1-21$ & 7 & 29 & 0.19815 & 0.19808 & $0-32$ & 4 \\
\hline 13 & 0.27385 & 0.27396 & -121 & 1 & 30 & 0.19407 & 0.19407 & -212 & 5 \\
\hline 14 & 0.25314 & 0.25308 & $-1-21$ & 8 & 31 & 0.19152 & 0.1915 & $2-31$ & 8 \\
\hline 15 & 0.25136 & 0.25137 & $2-10$ & 12 & 32 & 0.18938 & 0.18937 & $1-41$ & 9 \\
\hline 16 & 0.24391 & 0.24392 & -211 & 14 & 33 & 0.18625 & 0.18621 & $-2-12$ & 3 \\
\hline 17 & 0.24020 & 0.24018 & $2-20$ & 6 & 34 & 0.18417 & 0.18418 & 130 & 2 \\
\hline
\end{tabular}

subjected to indexing. Calculated unite cell parameters are given in Table 3. Table 4 presents result of indexing of powder diffraction pattern of the triclinic $\beta-\mathrm{Li}_{4} \mathrm{WO}_{5}$ obtained in this work. Despite the fact that indexing results are in good agreement with literature data $[15,22]$ (Tables 1,3) we turn our attention to powder diffraction pattern of high-temperature modification of $\mathrm{Li}_{4} \mathrm{WO}_{5}, \beta$ $\mathrm{Li}_{4} \mathrm{WO}_{5}$. Figure 1 shows fragments of powder diffraction patterns of orthorhombic $\mathrm{Li}_{4} \mathrm{WO}_{5}$ (generated on the basis of ICDD PDF 00-021-0530) (a), triclinic $\beta-\mathrm{Li}_{4} \mathrm{WO}_{5}$ obtained in this work (b) and triclinic $\mathrm{Li}_{4} \mathrm{WO}_{5}$ (generated on the basis of ICDD PDF 04-010-6772) (c). Analysis of the number of diffraction lines, their angular positions and relative intensities have revealed that diffraction pattern of triclinic $\beta-\mathrm{Li}_{4} \mathrm{WO}_{5}$ (Tables 1,3 ) obtained by us is very similar to diffraction pattern of high-temperature orthorhombic modification of $\mathrm{Li}_{4} \mathrm{WO}_{5}$ [15] and differs to some extent from PDF 04-010-6772 calculated on the basis of structural data of $\beta-\mathrm{Li}_{4} \mathrm{WO}_{5}$ [22]. The differences consist in splitting or overlapping of certain pairs of reflections, like (-110)-(001), (110)-(-1-11) or (101)-(1-21) and measurable shift of diffraction lines on powder diffraction pattern of sample obtained by us towards lower $2 \theta$ angles. As a consequence of it, unit cell parameters of $\beta$ $\mathrm{Li}_{4} \mathrm{WO}_{5}$ obtained by us are somewhat larger than these presented by Hoffmann and Hoppe [22] (Tables 1, 3). The differences in unit cell parameters are responsible for splitting or overlapping of certain reflections. It is worth to mention that single crystal which was used in the structure solving of $\beta-\mathrm{Li}_{4} \mathrm{WO}_{5}$ was obtained by heating a mixture containing components in atomic ratio $\mathrm{Li} / \mathrm{W}=4.4: 1$ at $950{ }^{\circ} \mathrm{C}$ for 28 days in gold tube. It is possible that lithium content in single crystal of $\beta-\mathrm{Li}_{4} \mathrm{WO}_{5}$ obtained by Hoffmann and Hoppe [22] was higher than assumed (Li/ $\mathrm{W}=4: 1$ ) or that temperature of $950{ }^{\circ} \mathrm{C}$ is necessary for ordering of ions in the lithium and tungsten sublattices. To clarify this problem, sample of $\beta-\mathrm{Li}_{4} \mathrm{WO}_{5}$ obtained at $700{ }^{\circ} \mathrm{C}$ was additionally heated for $2 \mathrm{~h}$ at $1000{ }^{\circ} \mathrm{C}$ and next cooled to room temperature and subjected to XRD phase analysis. Figure 2 shows fragments of powder diffraction patterns of $\beta-\mathrm{Li}_{4} \mathrm{WO}_{5}$ recorded after heating stage at $700{ }^{\circ} \mathrm{C}$ (a) and after additional heating at $1000{ }^{\circ} \mathrm{C}$ for $2 \mathrm{~h}$ 


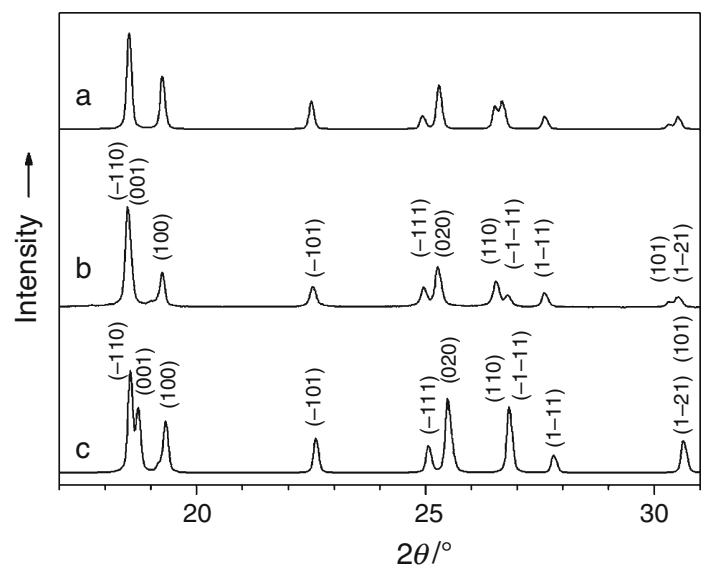

Fig. 1 Comparison of fragments of powder diffraction patterns of (a) orthorhombic $\mathrm{Li}_{4} \mathrm{WO}_{5}$ (generated on the basis of ICDD PDF 00-021-0530), (b) triclinic $\beta-\mathrm{Li}_{4} \mathrm{WO}_{5}$ obtained in this work and (c) triclinic $\mathrm{Li}_{4} \mathrm{WO}_{5}$ (generated on the basis of ICDD PDF 04-0106772)

(b). Results of phase analysis have revealed that sample after additional heating at $1000{ }^{\circ} \mathrm{C}$ except the $\beta-\mathrm{Li}_{4} \mathrm{WO}_{5}$ contains also $\mathrm{Li}_{2} \mathrm{WO}_{4}$ and $\mathrm{Li}_{2} \mathrm{O}$. It is in accord with literature data informing that at $1100{ }^{\circ} \mathrm{C} \beta-\mathrm{Li}_{4} \mathrm{WO}_{5}$ decomposes yielding $\mathrm{Li}_{2} \mathrm{WO}_{4}$ and $\mathrm{Li}_{2} \mathrm{O}$ [15]. As there were no evidences of splitting and overlapping of reflections as a result of heating at $1000{ }^{\circ} \mathrm{C}$, this problem requires further investigations.

The single-phase samples of $\mathrm{Li}_{2} \mathrm{WO}_{4}, \mathrm{Li}_{2} \mathrm{~W}_{2} \mathrm{O}_{7}$ and $\alpha$ $\mathrm{Li}_{4} \mathrm{WO}_{5}$ obtained after heating stages at $650{ }^{\circ} \mathrm{C}$ as well as $\beta-\mathrm{Li}_{4} \mathrm{WO}_{5}$ obtained after heating stage at $700{ }^{\circ} \mathrm{C}$ were subjected to the DTA-TG investigation up to $1000{ }^{\circ} \mathrm{C}$. Figure $3 \mathrm{a}$ shows DTA-TG curves of $\mathrm{Li}_{2} \mathrm{WO}_{4}$ and Fig. $3 \mathrm{~b}$ DTA-TG curves of $\mathrm{Li}_{2} \mathrm{~W}_{2} \mathrm{O}_{7}$. On each DTA curve was recorded only one endothermic effect, with their onsets at $745{ }^{\circ} \mathrm{C}$ for $\mathrm{Li}_{2} \mathrm{WO}_{4}$ and $735{ }^{\circ} \mathrm{C}$ in the case of $\mathrm{Li}_{2} \mathrm{~W}_{2} \mathrm{O}_{7}$.

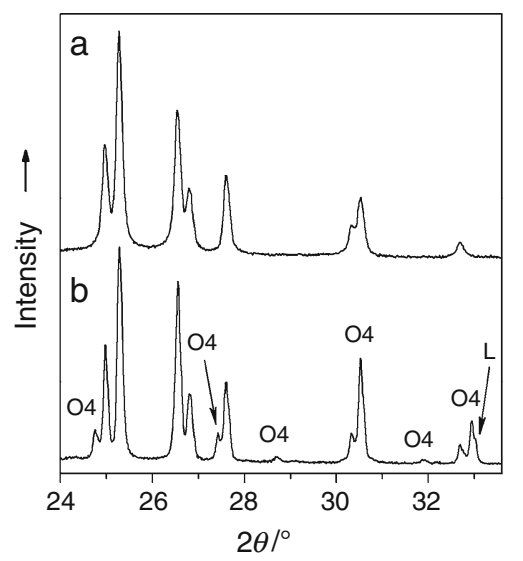

Fig. 2 Comparison of fragments of powder diffraction patterns of (a) $\beta-\mathrm{Li}_{4} \mathrm{WO}_{5}$ recorded after heating stage at $700{ }^{\circ} \mathrm{C}$ and after additional heating at $1000{ }^{\circ} \mathrm{C}$ for $2 \mathrm{~h}(b)$, where $\mathrm{O} 4$ stands for $\mathrm{Li}_{2} \mathrm{WO}_{4}$ and $\mathrm{L}$ stands for $\mathrm{Li}_{2} \mathrm{O}$
It was in accord with literature data where these endothermic effects were attributed to the melting of these phases [5-7, 11, 13, 14, 18]. TG curves of both phases did not contain any mass change effects. In order to explain melting behaviour of $\mathrm{Li}_{2} \mathrm{WO}_{4}$ and $\mathrm{Li}_{2} \mathrm{~W}_{2} \mathrm{O}_{7}$, samples of these compounds were additionally heated for $3 \mathrm{~h}$ at $780{ }^{\circ} \mathrm{C}$, i.e., at temperature close to the extremum temperature of the endothermic effects registered on the DTA curves.

At temperature $780{ }^{\circ} \mathrm{C}$, samples were liquid, colourless and transparent. After heating at $780{ }^{\circ} \mathrm{C}$, samples were cooled rapidly to room temperature. The X-ray phase analysis of the melted and next quenched samples showed that they comprised only $\mathrm{Li}_{2} \mathrm{WO}_{4}$ and $\mathrm{Li}_{2} \mathrm{~W}_{2} \mathrm{O}_{7}$, respectively, which suggests congruent melting in both cases. On the other hand, Fig. 4 shows the DTA-TG curves of $\beta$ $\mathrm{Li}_{4} \mathrm{WO}_{5}$ (3a) and $\alpha-\mathrm{Li}_{4} \mathrm{WO}_{5}$ (3b). On the DTA curve of $\alpha-$ $\mathrm{Li}_{4} \mathrm{WO}_{5}$ was recorded one small endothermic effect with onset temperature at $690{ }^{\circ} \mathrm{C}$ which was accompanied by small mass loss effect (2\%). TG curve of $\alpha-\mathrm{Li}_{4} \mathrm{WO}_{5}$ includes also another small mass loss effect $(0.8 \%)$ with onset temperature at $230{ }^{\circ} \mathrm{C}$, which was not accompanied by any thermal effects. The first mass loss effect the most probably can be attributed to desorption of water adsorbed by $\alpha-\mathrm{Li}_{4} \mathrm{WO}_{5}$. The endothermic effect with onset at $690{ }^{\circ} \mathrm{C}$ can be connected with phase transition to $\beta-\mathrm{Li}_{4} \mathrm{WO}_{5}$. This is in accord with results of our XRD investigations (Table 2) indicating run of phase transition leading from $\alpha$ $\mathrm{Li}_{4} \mathrm{WO}_{5}$ to $\beta-\mathrm{Li}_{4} \mathrm{WO}_{5}$ in the temperature range of $650-700{ }^{\circ} \mathrm{C}$ and literature data $[7,15]$. However, the nature of the second mass loss effect is unknown and cannot be explained using only results of DTA-TG investigations. On the DTA curve of $\beta-\mathrm{Li}_{4} \mathrm{WO}_{5}$ was recorded only one endothermic effect with onset temperature at $210{ }^{\circ} \mathrm{C}$, which was accompanied by small mass loss effect $(2 \%)$. This mass loss effect was, however, greater than this

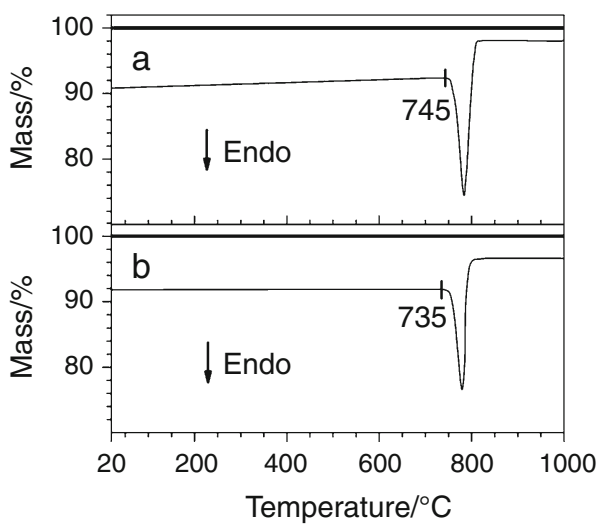

Fig. 3 DTA (light line) and TG (dark line) curves of pure: (a) $\mathrm{Li}_{2} \mathrm{WO}_{4}$ obtained after last heating stage at $650{ }^{\circ} \mathrm{C}$ and (b) $\mathrm{Li}_{2} \mathrm{~W}_{2} \mathrm{O}_{7}$ obtained after heating stage at $650{ }^{\circ} \mathrm{C}$ 


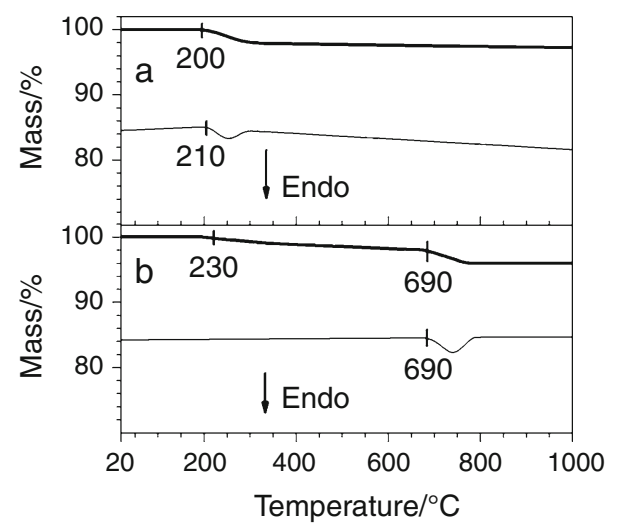

Fig. 4 DTA (light line) and TG (dark line) curves of pure: (a) $\beta$ $\mathrm{Li}_{4} \mathrm{WO}_{5}$ obtained after heating stage at $700{ }^{\circ} \mathrm{C}$ and $(b) \alpha-\mathrm{Li}_{4} \mathrm{WO}_{5}$ obtained after heating stage at $650{ }^{\circ} \mathrm{C}$

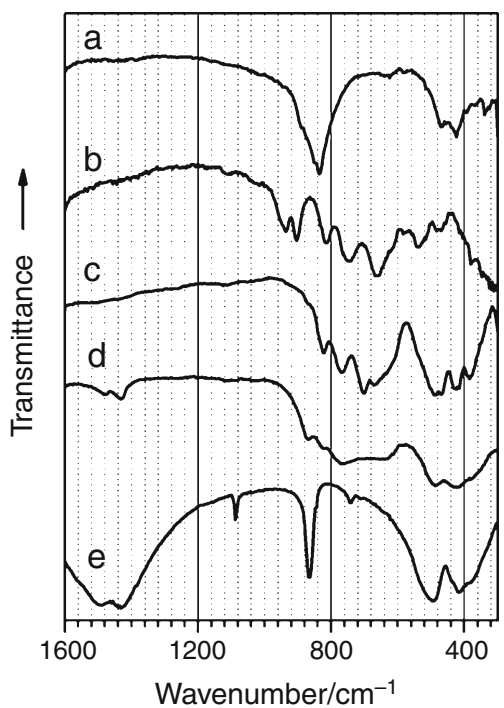

Fig. 5 IR spectra registered for pure samples obtained by the solid state reaction: (a) $\mathrm{Li}_{2} \mathrm{WO}_{4}$, (b) $\mathrm{Li}_{2} \mathrm{~W}_{2} \mathrm{O}_{7}$, (c) $\beta-\mathrm{Li}_{4} \mathrm{WO}_{5}$, (d) $\alpha$ $\mathrm{Li}_{4} \mathrm{WO}_{5}$ and $(e) \mathrm{Li}_{2} \mathrm{CO}_{3}$

recorded in the same temperature range on TG curve of $\alpha$ $\mathrm{Li}_{4} \mathrm{WO}_{5}$. This effect can also be connected with desorption of water adsorbed, this time, by $\beta-\mathrm{Li}_{4} \mathrm{WO}_{5}$ (Fig. 4).

In order to know better properties of obtained phases and to explain the nature of mass loss effects recorded on TG curves of $\alpha-\mathrm{Li}_{4} \mathrm{WO}_{5}$ and $\beta-\mathrm{Li}_{4} \mathrm{WO}_{5}$, single-phase samples of $\mathrm{Li}_{2} \mathrm{WO}_{4}, \mathrm{Li}_{2} \mathrm{~W}_{2} \mathrm{O}_{7}, \beta-\mathrm{Li}_{4} \mathrm{WO}_{5}$ and, $\alpha-\mathrm{Li}_{4} \mathrm{WO}_{5}$ were subjected to an investigation with the help of IR and UV-Vis-NIR/DRS spectroscopy. Figure 5 shows the IR spectra of $\mathrm{Li}_{2} \mathrm{WO}_{4}$ (curve a), $\mathrm{Li}_{2} \mathrm{~W}_{2} \mathrm{O}_{7}$ (curve b), $\beta-\mathrm{Li}_{4}$ $\mathrm{WO}_{5}$ (curve c), $\alpha-\mathrm{Li}_{4} \mathrm{WO}_{5}$ (curve d) and for comparison $\mathrm{Li}_{2} \mathrm{CO}_{3}$ (curve e), Fig. 6 shows UV-Vis-NIR/DRS spectra of $\beta-\mathrm{Li}_{4} \mathrm{WO}_{5}$ (square) and $\alpha-\mathrm{Li}_{4} \mathrm{WO}_{5}$ (circle), whereas

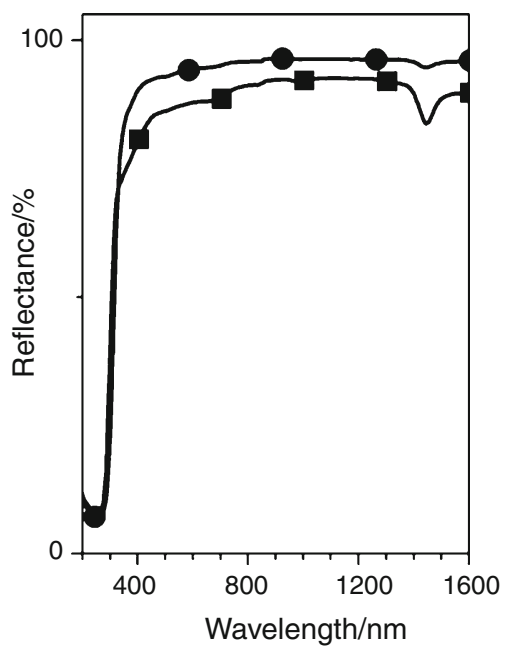

Fig. $6 \mathrm{UV}-\mathrm{Vis}-\mathrm{NIR} / \mathrm{DRS}$ spectra of $\alpha-\mathrm{Li}_{4} \mathrm{WO}_{5}$ (circle), $\beta-\mathrm{Li}_{4} \mathrm{WO}_{5}$ (square)

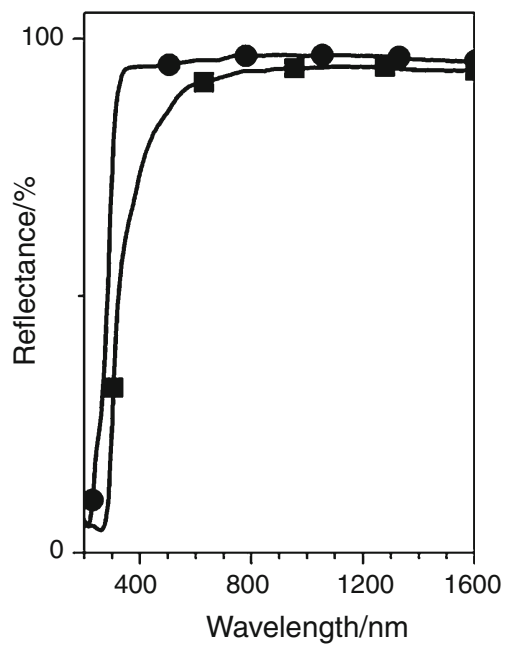

Fig. 7 UV-Vis-NIR/DRS spectra of $\mathrm{Li}_{2} \mathrm{~W}_{2} \mathrm{O}_{7}$ (square), $\mathrm{Li}_{2} \mathrm{WO}_{4}$ (circle)

Fig. 7 shows UV-Vis-NIR/DRS spectra of $\mathrm{Li}_{2} \mathrm{WO}_{4}$ (circle) and $\mathrm{Li}_{2} \mathrm{~W}_{2} \mathrm{O}_{7}$ (square).

Analysis of the number and positions of absorption bands recorded in the IR spectra of $\mathrm{Li}_{2} \mathrm{WO}_{4}, \mathrm{Li}_{2} \mathrm{~W}_{2} \mathrm{O}_{7}, \beta$ $\mathrm{Li}_{4} \mathrm{WO}_{5}$ and $\alpha-\mathrm{Li}_{4} \mathrm{WO}_{5}$ phases obtained in this work has shown good agreement with literature data in the wavenumber range of $1000-400 \mathrm{~cm}^{-1}[7,8]$. However, analysis of IR spectra in the range of $1600-1000 \mathrm{~cm}^{-1}$, not investigated earlier by other authors, has revealed in spectrum of $\alpha-\mathrm{Li}_{4} \mathrm{WO}_{5}$ (Fig. 5, curve d) weak absorption bands with maxima at 1430 and $1480 \mathrm{~cm}^{-1}$, characteristic for carbonates [31]. Similar bands, however much stronger, occur in IR spectrum of $\mathrm{Li}_{2} \mathrm{CO}_{3}$ (Fig. 5 curve e) but are 
absent in the spectra of other investigated phases. Thus, from the analysis of the envelopes of recorded spectra shown in Fig. 5, let us come to conclusion that mass loss effect recorded at $690{ }^{\circ} \mathrm{C}$ on TG curve of $\alpha-\mathrm{Li}_{4} \mathrm{WO}_{5}$ can be attributed to elimination of carbonate groups from the crystal lattice of this phase. We cannot exclude, however, that carbonate groups are eliminated from amorphous admixture accompanied $\alpha-\mathrm{Li}_{4} \mathrm{WO}_{5}$, but not detectable by XRD. These both assumptions raise question concerning real composition of $\alpha-\mathrm{Li}_{4} \mathrm{WO}_{5}$.

On the other hand, analysis of the UV-Vis-NIR/DRS spectra of $\alpha-\mathrm{Li}_{4} \mathrm{WO}_{5}$ and $\beta-\mathrm{Li}_{4} \mathrm{WO}_{5}$ has shown that they contain weak absorption bands with maxima near $1430 \mathrm{~nm}$, characteristic for water [24, 32]. Intensity of this band is higher in the case of $\beta-\mathrm{Li}_{4} \mathrm{WO}_{5}$. Such bands do not occur in the spectra of $\mathrm{Li}_{2} \mathrm{~W}_{2} \mathrm{O}_{7}$ and $\mathrm{Li}_{2} \mathrm{WO}_{4}$ (Fig. 7). It indicates that the small mass loss effects recoded on TG curves of $\alpha-\mathrm{Li}_{4} \mathrm{WO}_{5}$ and $\beta-\mathrm{Li}_{4} \mathrm{WO}_{5}$ in the temperature range $200-230{ }^{\circ} \mathrm{C}$ can be connected with elimination of water during heating of these samples.

Based on recorded UV-Vis-NIR/DRS spectra and using procedures described in [33-35], band gap energy values for $\mathrm{Li}_{2} \mathrm{WO}_{4}, \mathrm{Li}_{2} \mathrm{~W}_{2} \mathrm{O}_{7}, \alpha-\mathrm{Li}_{4} \mathrm{WO}_{5}$ and $\beta-\mathrm{Li}_{4} \mathrm{WO}_{5}$ equal to $4.35,4.03,4.00$ and $4.12 \mathrm{eV}$, respectively, were calculated.

\section{Conclusions}

- Reinvestigations of the $\mathrm{Li}_{2} \mathrm{O}-\mathrm{WO}_{3}$ system have been performed with the aid of DTA-TG, XRD, IR and UVVis-NIR/DRS measuring techniques and $\mathrm{WO}_{3}$ and $\mathrm{Li}_{2} \mathrm{CO}_{3}$ as a reactants.

- Using applied procedure of synthesis, four single phases have been obtained: $\mathrm{Li}_{2} \mathrm{WO}_{4}, \mathrm{Li}_{2} \mathrm{~W}_{2} \mathrm{O}_{7}, \alpha-$ $\mathrm{Li}_{4} \mathrm{WO}_{5}$ and $\beta-\mathrm{Li}_{4} \mathrm{WO}_{5}$.

- Diffraction reflection characteristic for $\mathrm{Li}_{2} \mathrm{~W}_{5} \mathrm{O}_{16}, \mathrm{Li}_{2-}$ $\mathrm{W}_{4} \mathrm{O}_{13}$ and $\mathrm{Li}_{6} \mathrm{~W}_{2} \mathrm{O}_{9}$ was identified on powder diffraction patterns of several samples, but it was not possible to obtain these compounds as single phases.

- Formation of $\mathrm{Li}_{6} \mathrm{WO}_{6}$ has not been corroborated in our research.

- Results of DTA-TG and XRD investigations have revealed that phases $\mathrm{Li}_{2} \mathrm{~W}_{2} \mathrm{O}_{7}$ and $\mathrm{Li}_{2} \mathrm{WO}_{4}$ melt congruently at 735 and $745{ }^{\circ} \mathrm{C}$, respectively, whereas $\alpha-\mathrm{Li}_{4} \mathrm{WO}_{5}$ undergoes a phase transition to $\beta-\mathrm{Li}_{4} \mathrm{WO}_{5}$ at $690{ }^{\circ} \mathrm{C}$.

- Results of DTA-TG and IR investigations indicate that crystal structure of $\alpha-\mathrm{Li}_{4} \mathrm{WO}_{5}$ can be stabilized by a small amount of carbonate groups.

- Based on UV-Vis-NIR/DRS investigations, band gap energies for $\mathrm{Li}_{2} \mathrm{WO}_{4}, \mathrm{Li}_{2} \mathrm{~W}_{2} \mathrm{O}_{7}, \alpha-\mathrm{Li}_{4} \mathrm{WO}_{5}$ and, $\beta$ $\mathrm{Li}_{4} \mathrm{WO}$ were calculated.
Open Access This article is distributed under the terms of the Creative Commons Attribution 4.0 International License (http://crea tivecommons.org/licenses/by/4.0/), which permits unrestricted use, distribution, and reproduction in any medium, provided you give appropriate credit to the original author(s) and the source, provide a link to the Creative Commons license, and indicate if changes were made.

\section{References}

1. Prolong V, Venkatesh G, Malo S, Caignaert V, Baies R, Raveau B. Electrochemical synthesis of lithium-rich rock-salt-type oxide $\mathrm{Li}_{5} \mathrm{~W}_{2} \mathrm{O}_{7}$ with reversible deintercalation properties. Inorg Chem. 2014;53:522-7.

2. Singh DJ. Relationship of $\mathrm{Li}_{2} \mathrm{WO}_{4}$ to the scheelite tungstate scintillators: electronic structure and atomic positions from density-functional calculations. Phys Rev. 2008;B77:113101.

3. Nipan GD. Phase states of $\mathrm{Li} / \mathrm{W} / \mathrm{Mn} / \mathrm{SiO}_{2}$ composites in catalytic oxidative coupling of methane. Inorg Mater. 2015;51:389-95.

4. Lv P, Chen D, Li W, Xue L, Huang F, Liang J. Subsolidus phase relationships in the system $\mathrm{ZnO}-\mathrm{Li}_{2} \mathrm{O}-\mathrm{WO}_{3}$. J Alloys Compd. 2008;460:142-6.

5. Parmentier M, Reau JM, Fouassier C, Gleitzer C. Lithium polymolybdates and polytungstates. Bull Soc Chim Fr. 1972;5:1743-5.

6. Luke L, Chang Y, Sachdev S. Alkali tungstates: stability relations in the systems $\mathrm{A}_{2} \mathrm{O}-\mathrm{WO}_{3}-\mathrm{WO}_{3}$. J Am Ceram Soc. 1975;58:267-70.

7. Hauck J. Uranates(VI) and tungstates(VI) within the system $\mathrm{Li}_{2} \mathrm{O}-\mathrm{UO}_{3}-\mathrm{WO}_{3}$. J Inorg Nucl Chem. 1974;36:2291-8.

8. Kurilenko LN, Serebryakova NV, Saunin EI, Gromov VV, Sokolova NP. IR spectroscopy of the $\mathrm{Li}_{2} \mathrm{O}-\mathrm{WO}_{3}$ and $\mathrm{Li}_{2} \mathrm{O}-$ $\mathrm{MoO}_{3}$ systems. Bull Acad Sci USSR. 1988;37:839-44.

9. Horiuchi $\mathrm{H}$, Moriimoto $\mathrm{N}$. The crystal structure of $\mathrm{Li}_{2} \mathrm{WO}_{4}$-II: a structure related to spinel. J Solid State Chem. 1979;30:129-35.

10. Waltersson $\mathrm{K}$, Wilhelmi KA, Werner PE. The structure of $\mathrm{Li}_{2-}$ $\mathrm{WO}_{4}$ (IV). A high pressure polymorph of lithium wolframate. Cryst Struct Commun. 1977;6:225-30.

11. Pistorius CWFTJ. Phase behavior of Li2WO4 at high pressures and temperatures. Solid State Chem. 1975;13:325-9.

12. Yamaoka S, Fukunaga O, Ono T, Tizuka E, Asami S. Phase transformations in $\mathrm{Li}_{2} \mathrm{WO}_{4}$ at high pressure. J Solid State Chem. 1973;6:280-5.

13. Hartmann P. A uniform description of phenakite type structures as superstructures of beta- $\mathrm{Si}_{3} \mathrm{~N}_{4}$. Z Kristallogr. 1989;187:139-44.

14. Drobasheva TI, Bogoduhova NA, Buhalova GA. $\mathrm{Li}_{2} \mathrm{WO}_{4}-\mathrm{Na}_{2}$ $\mathrm{WO}_{4}-\mathrm{WO}_{3}$ system. Zh Neorg Khim. 1975;20:3097-102.

15. Reau JM, Fouassier C, Hagenmuller P. New oxygen phases in ternary system $\mathrm{A}_{2} \mathrm{O}-\mathrm{MO}_{3}$ of formulas $\mathrm{A}_{4} \mathrm{MO}_{5}$ and $\mathrm{A}_{6} \mathrm{MO}_{6}$ (A = Li, Na; M = Mo, W). Bull Soc Chim Fr. 1967;680:3873-6.

16. Hauck J. Zur Kristallstruktur des $\mathrm{Li}_{6} \mathrm{WO}_{6}$. Z Naturf. 1969;B24:251.

17. Parmentier M, Gleitzer C, Aubry J, Chaudron MG. Un tungstate basique de lithium $\mathrm{Li}_{6} \mathrm{WO}_{6}$. A basic lithium tungstate $\mathrm{Li}_{6} \mathrm{~W}_{2} \mathrm{O}_{9}$. C R Seances Acad Sci. 1972;274:1681-3.

18. Reau MJ, Fouassier C. Les systemes $\mathrm{MO}_{3}-\mathrm{A}_{2} \mathrm{O}(\mathrm{M}=\mathrm{Mo}, \mathrm{W}$; $\mathrm{A}=\mathrm{Li}, \mathrm{Na}, \mathrm{K})$. Bull Soc Chim Fr. 1971;2:398-402.

19. Okada K, Morikawa H, Marumo F, Iwai S. The crystal structure of $\mathrm{Li}_{2} \mathrm{~W}_{2} \mathrm{O}_{7}$. Acta Cryst. 1975;31:1451-5.

20. Blasse $\mathrm{G}$. On the structure of some compounds $\mathrm{Li}_{3} \mathrm{Me}^{5+} \mathrm{O}_{4}$ and some other mixed metal oxides containing Lithium. Z Anorg Allg Chem. 1964;331:44-50.

21. Wilhelmi KA, Waltersson K, Lofgren P. On the structure of a high pressure polymorph of lithium wolframate(VI), $\mathrm{Li}_{2} \mathrm{WO}_{4}(-$ III). Cryst Struct Commun. 1977;6:219-25. 
22. Hoffmann R, Hoppe R. Two new order variations of NaCl-type: $\mathrm{Li}_{4} \mathrm{MoO}_{5}$ and $\mathrm{Li}_{4} \mathrm{WO}_{5}$. Z Anorg Allg Chem. 1989;573:157-69.

23. Piatkowska M, Tomaszewicz E. Synthesis, structure, and thermal stability of new scheelite-type $\mathrm{Pb}_{1-3 \mathrm{x}} \square_{\mathrm{x}} \mathrm{Pr}_{2 \mathrm{x}}\left(\mathrm{MoO}_{4}\right)_{1-3 \mathrm{x}}\left(\mathrm{WO}_{4}\right)_{3 \mathrm{x}}$ ceramic materials. J Therm Anal Calorim. 2016;126:111-9.

24. Tabero P, Frackowiak A. Synthesis of $\mathrm{Fe}_{8} \mathrm{~V}_{10} \mathrm{~W}_{16} \mathrm{O}_{85}$ by a solution method. J Therm Anal Calorim. 2016;125:1445-51.

25. Tabero P. Formation and properties of the $\mathrm{Fe}_{8} \mathrm{~V}_{10} \mathrm{~W}_{16-\mathrm{x}} \mathrm{Mo}_{\mathrm{x}} \mathrm{O}_{85}$ type solid solution. J Therm Anal Calorim. 2007;88:37-41.

26. Bosacka M, Filipek E, Paczesna A. Unknown phase equilibria in the ternary oxide $\mathrm{V}_{2} \mathrm{O}_{5}-\mathrm{CuO}-\mathrm{In}_{2} \mathrm{O}_{3}$ system in subsolidus area. J Therm Anal Calorim. 2016;125:1161-70.

27. Checmanowski J, Pelczarska AJ, Szczygiel I, Szczygiel B. Influence of ceria and yttria on the protective properties of $\mathrm{SiO}_{2}$ $\mathrm{Al}_{2} \mathrm{O}_{3}$ coatings deposited by sol-gel method on $\mathrm{FeCrAl}$ alloy. J Therm Anal Calorim. 2016;126:371-80.

28. Souza MT, Cesconeto FR, Arcaro S, Teixeira AHB, RauppPereira F, Montedo ORK, Novaes de Oliveira AP. Synthesis and characterization of $\mathrm{Li}_{2} \mathrm{TiSiO}_{5}$ obtained by melting and solid-state reaction. J Therm Anal Calorim. 2017;127:463-7.

29. Świderski G, Lewandowska H, Świsłocka R, Wojtulewski S, Siergiejczyk L, Wilczewska A. Thermal, spectroscopic (IR, Raman, NMR) and theoretical (DFT) studies of alkali metal complexes with pyrazinecarboxylate and 2,3-pyrazinedicarboxylate ligands. J Therm Anal Calorim. 2016;126:205-24.
30. Gorodylova N, Kosinová V, Dohnalová Ž, Šulcová P, Bělina P. Thermal stability and colour properties of $\mathrm{CuZr}_{4}\left(\mathrm{PO}_{4}\right)_{6}$. J Therm Anal Calorim. 2016;126:121-8.

31. Gadsen JA. Infrared spectra of minerals and related inorganic compounds. London: Butterworths; 1975.

32. Gabrus E, Nastaj J, Tabero P, Aleksandrzak T. Experimental studies on $3 \mathrm{~A}$ and $4 \mathrm{~A}$ zeolite molecular sieves regeneration in TSA process: aliphatic alcohols dewatering-water desorption. Chem Eng J. 2015;259:232-42.

33. Kim K, Park JH, Kim H, Kim JK, Schubert EF, Cho J. Energy bandgap variation in oblique angle-deposited indium tin oxide. Appl Phys Lett. 2016;108(041910):1-4.

34. Joseph P, Petchimuthu K, Chinnapiyan V. Enhanced band gap energy and electrochromic behaviour of selenium incorporated copper thin film. J Phys Sci. 2016;27:41-54.

35. Liu P, Longo P, Zaslavsky A, Pacifici D. Optical bandgap of single- and multi-layered amorphous germanium ultra-thin films. J Appl Phys. 2016;119(014304):1-9. 